\title{
FRAMEWORKS FOR ETHICS IN PUBLIC HEALTH
}

\author{
Bruce Jennings*
}

\begin{abstract}
This paper constructs a conceptual framework for the normative study of public health. It argues that to develop discussions of ethics in public health without paying attention to the broader theoretical and ideological context of public health controversies and social conflicts will be of limited value. In defining that context, the author distinguishes three main types of ethical theory-utilitarianism, contractarianism, and communitarianism; and several varieties of political theory -liberal welfarism, liberal egalitarianism, libertarian liberalism, deliberative democracy, civic republicanism, and cultural conservatism. The meanings and interconnections of these theory formations are discussed. Illustrations to particular public health programs and issues are given. The paper also distinguishes four different types of applied ethical discourse in public health-professional ethics, advocacy ethics, applied ethics, and critical ethics. Each of these modes of ethics is important, but the development of work in critical ethics is the most important priority within the normative study of public health at present.
\end{abstract}

Keywords: public health, ethics, liberalism, rights, communitarianism, utilitarianism, contractarianism, health promotion, public health surveillance

\section{MARCOS CONCEPTUALES PARA LA ÉTICA EN SALUD PÚBLICA}

Resumen: Este texto construye un marco conceptual para el estudio normativo de la salud pública. Argumenta que desarrollar discusiones sobre la ética en salud pública será de escasa utilidad si no se presta atención al contexto más amplio, teórico e ideológico, de las controversias en salud pública y a los conflictos sociales. En la definición de ese contexto, el autor distingue tres tipos principales de teorías éticas - utilitarianismo, contractarianismo y comunitarianismoy diversas variantes de teoría política -liberalismo del bienestar, liberalismo igualitario, liberalismo libertario, democracia deliberativa, republicanismo cívico y conservatismo cultural-. Se discuten los significados e interconexiones de estas formaciones teóricas. Se ilustra su aplicación a programas y temas particulares de salud pública. El artículo también distingue cuatro tipos de discurso de ética aplicada en salud pública: ética profesional, ética de la abogacía, ética aplicada y ética crítica. Cada uno de ellos es importante, pero el desarrollo del trabajo en ética crítica constituye la prioridad más importante dentro del estudio normativo de la salud pública en la actualidad.

Palabras clave: Salud pública, ética, liberalismo, derechos, comunitarianismo, utilitarianismo, contractarianismo, promoción de la salud, vigilancia en salud pública

\section{MARCOS CONCEPTUAIS PARA A ÉTICA EM SAÚDE PÚBLICA}

Resumo: Este texto construi um marco conceitual para o estudo normativo da saúde pública. Argumenta que será de pouca utilidade alimentar discussões em torno da ética em saúde pública sem prestar atenção ao contexto mais amplo, teórico e ideológico, das controvérsias em saúde pública e aos conflitos sociais. O autor distingue três tipos principais de utilitarismo teórico ético: contratualismo, comunitarismo e vários tipos de políticas liberais teóricas de bemestarianismo; igualitarismo liberal; liberalismo libertário; democracia deliberativa, republicanismo cívico e convervativismo cultural. Discutem-se os significados e interconexões destas formulações teóricas. Apresentam-se programas e temas de saúde pública. Distinguem-se quatro tipos de discurso ético aplicado na ética de saúde pública profissional: defesa ética, ética aplicada e ética crítica. Cada um é importante, porém, neste momento, o desenvolvimento do trabalho em ética crítica constitui a prioridade mais importante no estudo normativo de saúde pública.

Palavras chave: Saúde pública, ética, liberalismo, direitos, comunitarianismo, utilitarismo, contratualismo, promoção da saúde, vigilância em saúde pública

Senior Research Scholar. The Hastings Center. Garrison, New York.

Correspondence: jennings@thehastingscenter.org 


\section{Introduction}

In this essay I propose one conceptual framework to guide the development of normative and interpretive studies in public health. By "normative and interpretive studies," I mean to include inquiry into the ethical dimensions of public health policy and practice and the ethical principles or standards that should guide the conduct of public health practitioners. But I also mean something broader than ethics in public health: I mean the study of the normative cultural and ideological context within which issues of public value are framed, made to clash, and resolved.

Public health has emerged during the past two hundred years as a product of many historical forces: the maturation of the modern state; the industrial and post-industrial phases of capitalism; changing environmental, workplace, and life-style factors that affect the health of populations and individuals; the development of social systems highly urbanized and stratified by class, race, and ethnicity; the growth of medical scientific knowledge and the development of effective vaccines and other pharmaceuticals; and, finally, the growing body of observational and statistical knowledge, from epidemiology and other fields, of the nature of health risks and the distribution of disease and dysfunction on a population basis. These factors have created new kinds of public health threats and problems, and this body of knowledge has pointed to new kinds of interventions(1).

The steady hallmark of the public health has been a focus on social and behavioral change. Social change, that is, in the direction of greater social and economic equality and greater access to the resources and conditions necessary for widespread health and the health of the least well off-sanitary living conditions, adequate medical care, and measures to limit risk and exposure to conditions that undermine health(2). None of these issues is free from normative challenge or from the requirement of public normative justification. Here we cannot rely on an understanding of science and epidemiology alone. For these controversies are rarely settled solely the basis of the best available scientific understanding(3). They involve the preexisting traditions, patterns, and conditions of normative argumentation and legitimation. Those preconditions of normative argument can be studied using the tools of history, philosophy, interpretive theory (hermeneutics), and social criticism(4,5). So we have before us a domain of inquiry into the normative and interpretive context -the context of social value and meaning- that surrounds public health. It is this domain that I propose to explore and map in this paper.

\section{The Normative Grammar of Public Health}

I begin with an attempt to map the prevailing array of ethical and political theories that interact and contest with one another in the discourse of political morality -justification and legitimationin the United States. My description is selfconsciously limited to political culture and discourse in the US at least as far as the terminology I employ is concerned. However, the basic concepts underlying the typology offered here is much more widely shared in the world today, although the configuration will differ in its nuances and details.

Figure 1 presents one scheme for classifying the main types of ethical and political theory that play a role in the normative argument within and about public health. This represents the universe of normative discourse with which those in public health should be familiar. A few caveats should be noted.

In the case of both ethical theory (moral philosophy) and political theory, the configurations I have chosen to highlight are 
Figure 1. Aspects of Ethical and Political Theory in Public Health

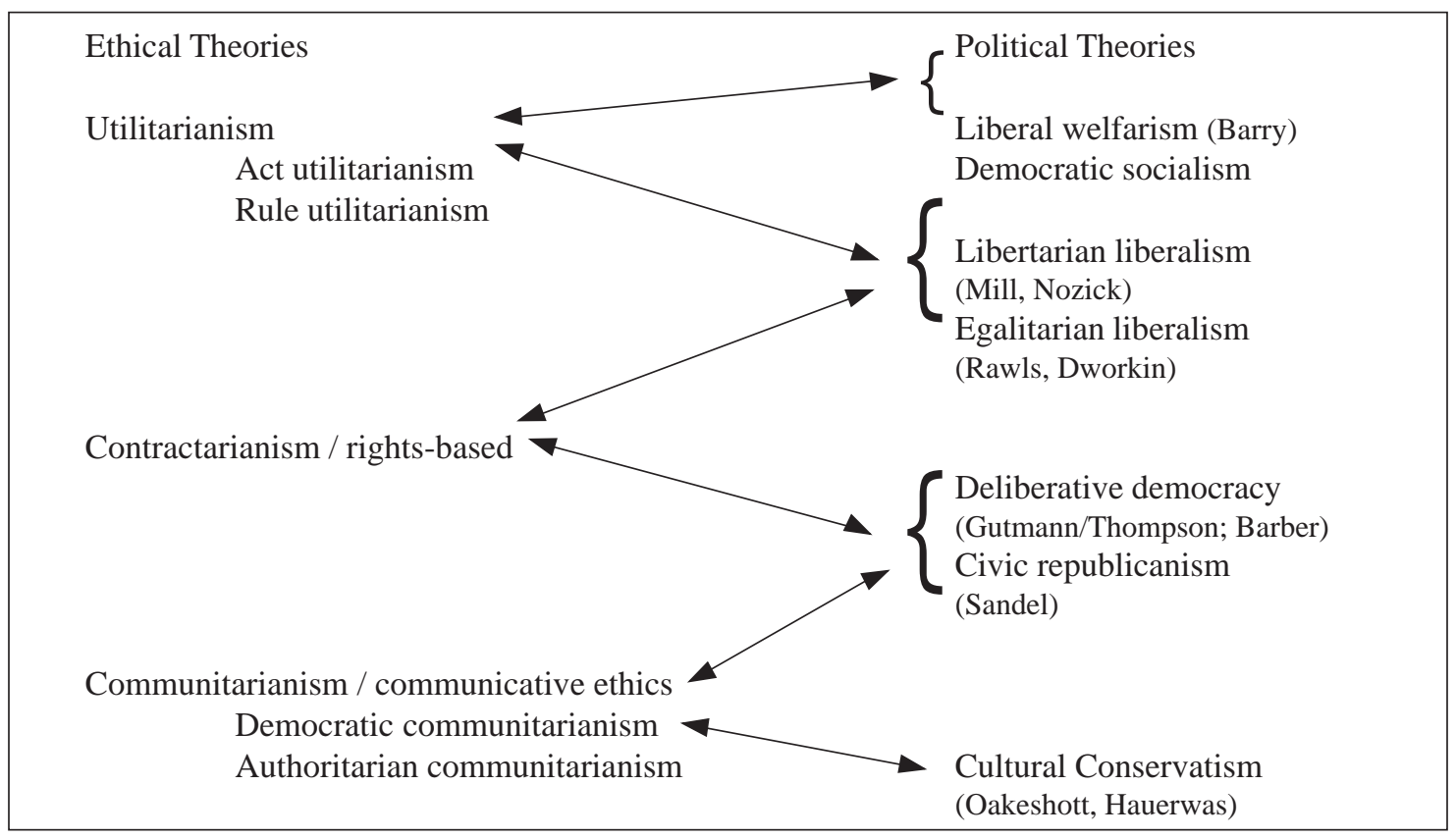

not the only ones that could be mentioned by any means(6). Moreover, I group together theoretical and philosophical orientations that, while having a certain family resemblance with one another, especially in contrast with other theoretical approaches, nonetheless have important internal differences. Partisans of any particular theory will no doubt object to such a grouping. Thus, I consider contractarian, neoKantian, and rights-based ethical theories together as one configuration, despite many important differences within and among them. For the purposes of this discussion, I believe we can gloss over these differences.

Even more simplistic is the attachment of any significant theorist with any of these types. Theorists destined for canonization in the Western political tradition, such as John Stuart Mill and John Rawls, create complex intellectual systems that draw from a variety of sources and traditions. These theorists show such originality in their deployment of key concepts that they defy any such simple characterization or "-ism". The same is true for each of the other important and original thinkers whose names I have attached to this figure(7-16). (There are many others who could as well have been mentioned, for the literature in each of these theoretical orientations is voluminous). It is with many reservations that I have added names at all, and I have done so only to provide a rough orientation to those who may find my descriptive terminology unfamiliar.

There are three basic types of ethical theory at work in contemporary moral discourse and in discussions of ethical issues in public health. The first is utilitarianism, with its many standards of evaluation (pleasure, happiness, utility) and its varieties of form (whether it is applied to individual acts or to general rules or patterns of behavior; whether the evaluation uses averaged or weighted units)(17). It is not surprising that utilitarianism should remain a significant aspect of public moral discourse. Its consequentialist orientation is appealing in a largely materialistic, empirically minded, and pragmatic cultural milieu. It seems to offer the most rigorous, even quantitative, approach to 
normative questions, and this comports well with fields such as economics, policy analysis, and public health which have roughly the same normative and epistemic biases. It offers something like a lingua franca among policy makers for the purposes of determining large scale policy or distributional issues(11).

The second main cluster of ethical theories, contractarianism, has coexisted uneasily with utilitarianism since the late eighteenth century, and has been given a new invigoration in recent decades by the work of John Rawls. Rawls not only developed a new and quite sophisticated version of the contractarian theoretical apparatus, but also developed a powerful critique of contemporary utilitarianism by essentially showing that utilitarian accounts of justice were unable to take the differences among individuals, or the unique moral value of each individual, seriously(10). In his later work, he has gone on to claim that some version of his type of theory reflects more cogently and accurately the actual moral beliefs of people in the Western countries, if not the global community(18).

The keystone of this type of theory is that it grounds the justification of moral argument on the notion that any moral claim must be reasonably acceptable to a group of free and equal individuals deliberating on the basis of certain norms of reason and open discourse. Respect for the freedom and equal moral worth of each individual may be expressed in a slightly different way by an enumeration of fundamental political, social, and human rights that are shared by all persons; not on the basis of the (good) consequences of recognizing those rights, but on the basis of their intrinsic value and rightness(19).

The third formation of ethical theories that must be taken into consideration are a disparate class of so-called "communitarian" orientations(20). Communitarian ethics arose to some extent in reaction to what was perceived as the excessively individualistic character of contractarian ethics. Individuals seem to be free-standing and sui generis beings, without connection to others or society and without formation through the medium of a preexisting culture or tradition. Contractarians are critical of utilitarians for taking the individual to be little more than a utility maximizing strategic player in a social competition where the overall outcome -not the individual players- matter. In a similar vein, communitarians fault both the utilitarians and the contractarians for having an inadequate conception of the human person and for paying insufficient attention to the moral importance of the fabric that binds human beings together in a mutually beneficial, caring, and nurturing society. Communitarians have also been critical of an emphasis on the rights (claims, powers, and privileges of a person against society) of individuals without a corresponding emphasis on the responsibilities of individuals to the society or community to which they belong $(21,22)$.

It is not difficult to understand why communitarian ethics takes on both a kind of leftleaning egalitarian and participatory democratic turn and a more culturally conservative and authoritarian turn. One orientation strongly committed to social change and cultural transformation, feminist philosophy and the feminist movement, has been an important source of communitarian ethics. This shows how and why communitarianism can move in a progressive direction. Although persons are shaped by culture and relationships, they also shape them, and those cultural traditions, distributions of power, and relationships that are discriminatory and oppressive to certain types or classes of people should be transformed, not for the sake of greater individual liberation and autonomy in some abstract 
sense, but for the sake of better, more humanly self-fulfilling patterns of relationships and sharing of power(23).

By the same token, an emphasis on the need of the individual for stability, order, and cultural roots, coupled with a sense of the limitations of human reason, either as a motivating factor in human conduct or as a faculty that can successfully design and guide deliberate social change, can take the communitarian orientation in a much more conservative and authoritarian direction. In this it has affinities with the conservative (aristocratic) heritage, with the civic republican tradition (given its emphasis on individual duty, virtue, and common morality), and with the worldview of religious orthodoxy and fundamentalism.

For its part, communicative ethics, growing largely out the tradition of German critical theory in the work of Jürgen Habermas and others, is perhaps more closely allied with contractarianism than other forms of communitarianism, and it can be quite formalistic and Kantian in character(24). But several theorists of communicative ethics have turned away from theoretical constructs, such as the "original position" (Rawls) or the "ideal speech situation" (Habermas), and toward real world social discourse and deliberation, as the basic justifying grounds for ethical argument(25).

Turning to political theory, it is not so easy to group various approaches into three clusters. The basic starting point for understanding American political theory is that most often both public argument and political conflict over ideology and policy have taken place within the parameters of the broad tradition of political and philosophical liberalism that Americans inherited from English revolutionary and Enlightenment thought. With rather short lived and localized exceptions, there has never developed a seriously authoritarian left-wing nor an authoritarian right-wing political theory in the United States. Thus the classification suggests a large range of variations on liberalism, with a left-communitarian-style emphasis on a more participatory form of democracy, on the one hand, and a right-communitarian-style cultural conservatism, on the other. These two forms of communitarianism, and not an old communist left nor a fascist right, make up what amounts to the main challenges to mainstream liberalism in America today.

Within the spectrum of liberalism broadly construed (including large portions of what is ordinarily called "conservativism" in the United States), we have variants that are close to being socialist and collectivist in nature, and these seem to me to grow mainly out of the utilitarian tradition. If one took a survey designed to get at something like these orientations among professionals in the field of public health, my hunch is that one would find large numbers occupying this area. What I am calling "egalitarian liberalism” is also of the left in that it favors the use of national state power to promote a more equal distribution of wealth and power in the society, a conception of justice that requires primary attention to the interests of the least advantaged, and the close regulation of corporate and private economic activity to mitigate deleterious environmental, social, and health effects. It draws theoretical justification from the individualistically oriented theorists of freedom, justice, equality and human rights that comprise the contractarian approach. Rounding out the liberal spectrum is libertarian liberalism, which favors maximum freedom of individual choice with a minimum of governmental power or coercion. Institutions that bring about social order and cooperation on the basis of unplanned and uncoordinated actions and choices of free individuals (e.g. the market model in theory) are preferred by libertarians over the achievement of social order and the public interest via governmental 
regulation and the exercise of the "police power" or the paternalistic authority of the state.

Liberalism of all types tends to presuppose an institutional framework of representative democracy, the rule of law, freedom of speech and political organization, and competitive elections. Liberalism and democracy were not always thought to be mutually compatible, but today they are joined at the hip at least in Western political thinking(26). (That may be why a regime such as China, which seems to have pried apart economic liberalism from political democracy, embracing the former while rejecting the latter, presents us with something of an enigma). Perhaps the most theoretically innovative and interesting challenge to this liberal paradigm arises from forms of democratic theory that are not satisfied with current institutions of electoral politics and representative, interest group democracy. One such form, that is close to egalitarian liberalism in many ways, but which nonetheless demands a more direct, active role in both political argument and in civic and political life, is known as deliberative or discursive democracy $(27,28)$. It also has a great deal in common with leftcommunitarianism, as was noted above.

Another major type of political theory that rivals liberalism, and has long pedigree in the history of Western political theory, has come to be known as civic republicanism. With intellectual roots that can be traced back to classical political thought in ancient Greece and Rome, republicanism was rekindled during the Renaissance, by thinkers such as Machiavelli, and later transmitted to various English revolutionaries in the seventeenth century(29). At that time, democracy was hardly mentioned, but establishing a republic was seen as the main alternative to hereditary and absolute monarchy, which had become the principal governmental form of the powerful nation states in the early modern period (France, Spain, England, Russia, the Holy Roman Empire). In American history republicanism was an important ideological foundation of the revolution and of the governing of the country during its first one hundred years $(14,30)$. It was not until the period of the industrial revolution in the late nineteenth century that more individualistic public philosophies -such as Lockean liberalism, libertarianism, natural rights theories and the more materialistic and economically oriented versions of utilitarianism-drove republicanism into abeyance. With its sense of the common good and its emphasis on public service and civic virtue, however, civic republicanism is proving to be a theoretical vocabulary of renewed vitality in recent years. It is a straightforward ally of communitarianism and deliberative democracy in many settings.

Finally, no schema of contemporary American political thought would be complete without mention of the kind of cultural conservatism that is so powerfully associated with the fundamentalist and religious revitalization movement now underway here(31). Fortunately this movement has not taken on a guise of collectivism in the manner of national socialism or fascism, although its opposition to the power of government regulation and control seems to be waning during a presidential administration and a congressional majority that seems sympathetic. For the most part, however, this movement has embraced economic and political liberalism but oriented toward the goals of cultural and sexual conservatism and protestant Christian religious fundamentalism.

It is not possible to construct a one-on-one mapping of ethical theories with political theories. The lines drawn on Figure 1 are meant to indicate that there is a two-way pattern of influence between political and ethical thinking, 
and that each configuration of political theory can draw from several different sources within ethical theory. In On Liberty, for example, John Stuart Mill develops a position closely akin to libertarian liberalism on the basis of a utilitarian metatheory, while Robert Nozick grounds his libertarianism on rights-theory and contractarianism(8,9).

Similarly, contractarianism provides the theoretical underpinnings for both egalitarian liberalism and some aspects of deliberative democracy. The main disagreement between these two camps would not be over fundamental values and principles, but over the most effective means to formulate policy and to build support for it in a process of democratic will formation (the democrats prefer actual deliberation over hypothetical deliberation). On the other hand, deliberative democrats and civic republicans (these terms have no relationship whatsoever to the American Democratic and Republican political parties) draw much in common from the insights of communitarianism about the moral and human importance of relationships of friendship and shared commitment, cultural tradition, and a sense of community. Yet they may differ considerably about the importance and the practicality of direct grassroots participation in deliberation and policymaking. The republican tradition has never insisted on direct democracy; indeed it is more characteristic of republicans to look toward governance by elites or experts, tempered perhaps by representative democracy and constitutional and other judicial protections. This is because the goal of civic republicanism is not active participation in shared decisionmaking per se (public citizenship), but rather the preservation of the public morality and a sense of duty and responsibility among private citizens whose behavioral support and restraint are necessary to achieve public goals and to realize the common good.

\section{Normative Discourse in Public Health Practice}

It is my hope that the preceding sketch, brief and oversimplified as it has been, nonetheless conveys a sense of the normative complexity of the semantic field within which public health policies and programs find themselves vying for parliamentary support, funding, and social legitimacy. This is not the place to elaborate on how various public health issues can be interpreted in light of the basic formations of ethical and political theory outlined above. Let me mention just a few areas where I believe one cannot understand the arguments that swirl around public health measures without sorting out the ideological and theoretical landscape as I have begun to do here.

One important area of normative controversy in public health is in health promotion and disease prevention. Such programs inevitably raise questions about the responsibility of individuals to live healthy lives; about the role of government in coercing health-related behavior or in developing educational programs; about the use of incentives, economic or otherwise, to promote good health; and about the relative importance for society of pursuing good health, particularly in a culture that prizes autonomy and does not always look fondly on government intervention.

A second area of public health controversy centers around the goal of risk reduction. Risks to the health of the public are many, and many methods are used to reduce or eliminate them. Almost everyone of them can pose one or more ethical problems. The concept of risk itself is seemingly impossible to define in value neutral terms and is inherently controversial. Even more ethically charged is the question of what level or degree of risk is socially acceptable, who should decide, and how should exposure to risk be distributed across the affected 
population. Routine public health practice involves a number of interventions and policies designed to prevent harm to individuals and to lower health risks within the population. These include various forms of public health surveillance -screening and testing- on different age groups, many of which are legally mandatory and paternalistic or are administered in a way that does not follow the requirements of informed consent. Epidemiological research may not always follow strict ethical protocols on the rights of human subjects, and the collection of health information may sometimes put the researcher in a position of having information that a specific individual might have an interest in knowing. The responsibilities of the public health researcher regarding individual notification and the protection of personal privacy and confidentiality are not yet clearly set out as a matter of consensus within the profession. Like the prevention of harm to others, individual privacy is a lightening rod for the conflicts and tensions between individual liberties and the common good that the main ethical and political theories of our time attempt to adjudicate and set in order.

Finally, there is the issue of structural and socioeconomic disparities in health status. Equitable access to decent health care and reduction in health status disparities have been long-sought goals in American society. What is the appropriate role for the public health community in seeking greater justice in health care, and how ought it to balance its fact-finding and educational role over against its historically strong advocacy mission. To what extent, if any, ought the field adopt a politically partisan posture?

\section{Styles of Practical Ethical Discourse}

To complete my analysis of normative inquiry in public health I turn from ethical theories to the available orientations and styles of practical or applied ethical analysis. As before, we need some rough typology or conceptual map to guide further research and interpretation in the normative study of public health. To borrow an analogy from linguistics, if ethical and political theories form the grammar (la langue) of normative discourse in public health, these styles or rhetorics of ethical discourse form its speech acts (la parole).

I want to distinguish four different styles of applied ethics: professional ethics, advocacy ethics, applied ethics, and critical ethics.

Professional ethics. The study of professional ethics tends to seek out the values and standards that have been developed by the practitioners and leaders of a given profession over a long period of time, and to identify those values that seem most salient and inherent in the profession itself. Applied to public health, this perspective entails identifying the central mission of the profession (e.g. protection and promotion of the health of all members of society) and building up a body of ethical principles and standards that would protect the trust and legitimacy that the profession should maintain. Like all professionals, public health officers exercise considerable power over the lives of others, and the way they use that power makes a substantial difference in the quality of those lives. The perspective of professional ethics would seek to express the virtues that practitioners ought to possess and the rules they ought to follow if they are to be permitted by society to exercise such power and authority.

A difficulty in using this approach in the arena of public health is the questionable, tenuous status of public health as a single, unified profession today. The power of this ethical approach usually comes from the fact that students and practitioners feel that they have taken on a special role-duty or "calling" when they enter the profession. This ethos and 
sensibility seem to be lacking in public health at the moment.

Advocacy ethics. If there is a characteristic ethical orientation within the field of public health today, it is probably less theoretical or academic than practical and adversarial. The ethical persuasion most lively in the field is a stance of advocacy for those social goals and reforms that public health professionals believe would enhance the general health and wellbeing, especially of those least well off in society. Such advocacy is in keeping with the natural priorities of those who devote their careers to improving public health. It has a strong orientation toward equality and social justice, for so much of the research and expertise in public health throughout its history has focused on showing how social deprivation, inequality, poverty, and powerlessness are directly linked to poor health and the burden of disease. In recent years a growing international movement in support of human rights has exerted an important influence in public health as well(32). And it has moved public health ethics in its advocacy mode toward an agenda of social and welfare rights designed to provide resources and to empower individuals and groups, and not just to protect the so-called "negative" or political rights of the individual against intrusion or harm.

The problem raised by this perspective on ethics is the flip side of its passion and commitment. Precisely because it backs the professional service agenda of the field of public health, it has only a limited ability to provide a critical perspective on norms and orientations that are taken for granted in the field. As an ethical approach it aims more toward action than persuasion. It has little to calm and reassure those outside the field who may question the legitimacy of public health's use of its governmental or social power. By definition an advocacy position is not primarily based on detached rational persuasion. To look beyond the advocacy ethics of public health we need to find an orientation no less critical of powerful interests, but one more committed to careful and inclusive deliberation; deliberation undertaken in an effort to set aside specific moral commitments and political agendas on behalf of gaining some broader perspective in the moral questions at issue.

Applied ethics. Another approach to public health ethics comes from the field that has emerged in recent years as "applied" or "practical” ethics. Bioethics is one area among others within this domain of ethics. The applied ethics perspective differs from the professional ethics perspective principally in that it adopts a point of view from outside the history and values of the profession. From this more general moral and social point of view, applied ethics seeks to devise general principles that can then be applied to real world examples of professional conduct or decisionmaking(33). These principles and their application are designed to give professionals guidance and to give clients and the general public standards to use in assessing professional conduct. Thus in applied ethics there is a tendency to reason abstractly and to draw from general ethical theories, rather than from the folkways and knowledge base of the professions. The emphasis tends to be on professional conduct rather than on the virtues of professional character.

One difficulty in using the applied ethics approach is that it has been individualistic and client-rights oriented. It works most effectively, therefore, in what might be called client-centered as opposed to "public" professions(34). For professions like public health the obligations and service pertain to a set of institutions, to a particular structure or arrangement of social 
relationships, and to the overlapping interests of large groups of people. When collective nouns, such as "the public", "society", "the community”, “children”, or "persons at risk for diabetes", feature in the ethical obligations and principles of a given field, the applied ethics perspective has difficulty formulating ethical guidance that is philosophically coherent and practically useful. The same could be said when collective values (such as the common good or the public interest) are at the center of ethical controversies in the field, as they surely are and must be-in public health.

Critical ethics. Finally, I would distinguish yet another possible perspective on ethics that could be directed toward the distinctive issues and problems of public health. For want of a better term, I call it "critical ethics(35)". In many ways it attempts to combine the strengths of the other perspectives mentioned. Like professional ethics, it is historically informed and practically oriented toward the specific real world and real time problems of public health, but like applied ethics it brings larger social values and historical trends to bear in its understanding of the current situation of public health and the moral problems faced. These problems are not only the result of the behavior of certain disease organisms or of particular individuals. They are also the result of institutional arrangements and prevailing structures of cultural attitudes and social power. At one level, public health has always known this larger critique and has always stressed it; but of late, in its actual programmatic behavior, public health, like so much else in American culture, has neglected the project of institutional change and focused on the individual as the object of education, health promotion efforts, and life-style change(36).

The perspective of critical ethics has much in common with the egalitarian and human rights oriented discourse of advocacy ethics in public health. One advantage critical ethics may have is that it calls upon the discussion of ethics and public health policy to be genuinely public or civic endeavors. Not the advocacy of a wellintentioned elite on behalf of needy clients, but the search for forums and programs of meaningful participation, open deliberation, and civic-problem solving and capacity building. Some of the best examples of public health practice, from this point of view, grow out of efforts to support communities in being places of mutual support, respect, and self-esteem, thereby reinforcing health promoting behaviors among their individual members(37).

\section{Conclusion}

These different types of ethical analysis distinguish between the ethics of public health (how it frames and analyses the ethical problems it encounters), and the ethics within public health (how its practitioners understand their role, their values, and the criteria for judging the ethical perspective they bring to bear on their professional work). Many problems will require moving back and forth between the two levels. At the same time, there may well be a tension between the general values of society (e.g., its individualism) and the special values of public health (e.g., it population rather than individual orientation).

In the United States, we have traditionally been resistant to overall theories of the human good for individuals and the good of society. Yet a rich discourse on ethics and public health cannot be advanced without relating it to the background values of the general society, and the particular communities, in which it will be carried out. In Canada, for example, public health experts have much more consciously tried to relate public health and the sociopolitical values of Canadian society. It is one thing to say that public health rests on a 
communitarian foundation and quite another to determine how best to relate that foundation to our individualistic culture, particularly one historically hostile to government. The conflict, long endemic in our society, between rights to pursue self-interests and duties to sacrifice selfinterest to the interests of others or the common good, does not make it easy to develop population-based health strategies that must, on occasion, pressure rather than persuade, require rather than invite. That seems easier for Canadians or for European countries with a stronger tradition of solidarity. But an effort to think the problem through requires a more open recognition of the tensions, which may be decreasing rather than increasing, both within the varieties of contemporary liberalism and between liberalism and its alternatives.

\section{References}

1. Rosen GA. History of public health. Baltimore: Johns Hopkins University Press; 1993.

2. Institute of Medicine. The future of public health. Washington DC: Academy Press; 1988.

3. Wildavsky A. But is it true? A citizen's guide to environmental health and safety issues. Cambridge, Mass.: Harvard University Press; 1995.

4. Pocock JGA. Politics, language, and time. New York: Atheneum; 1973.

5. Walzer M. Interpretation and social criticism. Cambridge, Mass.: Harvard University Press; 1987.

6. Singer P, ed. A companion to ethics. Oxford: Blackwell; 1991.

7. Barry B. Political argument. London: Routledge \& Kegan Paul; 1965.

8. Mill JS. On liberty. Indianapolis: Bobbs-Merrell; 1971.

9. Nozick R. Anarchy, state, and utopia. New York: Basic Books; 1974.

10. Rawls J. A theory of justice. Revised edition. Cambridge, Mass: Harvard University Press; 1999.

11. Dworkin R. Taking Rights Seriously. Cambridge, Mass.: Harvard University Press; 1977.

12. Gutmann A, Thompson D. Democracy and disagreement. Cambridge, Mass: Harvard University Press; 1996.

13. Barber B. Strong democracy. Berkeley: University of California Press; 1986.

14. Sandel M. Democracy and its discontents. Cambridge, Mass: Harvard University Press; 1996.

15. Oakeshott M. Rationalism in politics and other essays. New and expanded ed. Indianapolis: Liberty Press; 1991.

16. Hauerwas S. Truthfulness and tragedy. South Bend, Ind.: University of Notre Dame Press; 1977.

17. Lyons D. Forms and limits of utilitarianism. Oxford: Oxford University Press; 1965.

18. Rawls J. Political liberalism. New York: Columbia University Press; 1993.

19. Feinberg J. The Nature and Value of Rights. In: Feinberg J, ed. Rights, justice, and the bounds of liberty: essays in social philosophy. Princeton: Princeton University Press; 1980: 143-58. 
Frameworks for Ethics in Public Health - B. Jennings

20. Etzioni A. The spirit of community: rights, responsibilities, and the communitarian agenda. New York: Crown Publishers; 1993.

21. Mulhall S, Swift A. Liberals and communitarians. 2d ed. Oxford: Blackwell; 1996.

22. Selznick P. The moral commonwealth; social theory and the promise of community. Berkeley: University of California Press; 1992

23. Walker MU. Moral understandings; a feminist study in ethics. New York: Routledge; 1998.

24. Habermas J. Moral consciousness and communicative action. Cambridge, Mass: MIT Press; 1990.

25. Benhabib S, Dallmayr F, eds. The communicative ethics controversy. Cambridge, Mass: MIT Press; 1990.

26. Macpherson CB. The life and times of liberal democracy. Oxford: Oxford University Press; 1977.

27. Dryzek J. Deliberative democracy and beyond. New York: Oxford University Press; 2000.

28. Macedo S, ed. Deliberative politics. New York: Oxford University Press; 1999.

29. Pocock JGA. The machiavellian moment: Florentine political thought and the Atlantic republican tradition. Princeton: Princeton University Press; 1975.

30. Bailyn B. The ideological origins of the American revolution. Cambridge, Mass: Harvard University Press; 1967.

31. Lakoff G. Moral politics: what conservatives know that liberals don't. Chicago: University of Chicago Press; 1996.

32. Mann JM, Gruskin, S, Grodin MA, Annas GJ, eds. Health and human rights. New York: Routledge; 1999.

33. Beauchamp T, Childress J. Principles of biomedical ethics. 5th ed. New York: Oxford University Press; 2001.

34. Jennings B, Callahan D, Wolf S. The professions: public interest and common good. Hastings Center Report February 1987, Special Supplement; 17 (1): 3-10.

35. Jennings, B. Bioethics and democracy. Centennial Review 1990; 34 (2): 207-25.

36. Bellah R, et al. The good society. New York: Vintage Books; 1992.

37. Putnam R. Bowling alone. New York: Simon and Schuster; 2000: 326-35. 